\title{
South African War (1899-1902) memorials in Britain: a case study of memorialisation in London and Kent
}

The South African War has spawned a substantial bibliography covering an extensive range of aspects and topics. In Britain, the historiography was reinvigorated in the late 1960s when the conflict was rediscovered after years of neglect with Thomas

Pakenham's monumental study, The Boer War (1979), playing a significant role in the renaissance of interest. However, there remains an important gap in research in the form of the conflict's memorialisation in Britain. Almost nothing has been written on this subject; by contrast, there is much work on the commemoration in South Africa and the participating Dominions of Australia, Canada and New Zealand. ${ }^{1}$ Until very recently the sole work on South African War commemoration in Britain was James Gildea's 1912 volume, For Remembrance, a beautifully produced, fully-illustrated, although by no means comprehensive, gazetteer of memorials published by Eyre and Spottiswoode with all profits directed to the Soldiers' and Sailors' Families Association. Over the last few years some new research has been carried out. Martin Staunton surveyed memorials in Ireland, and Edward Spiers has written on the importance of Boer War commemoration in Scotland in his book, The Scottish Soldier and Empire, 1854-1902. ${ }^{2}$ Most recently David Thompson has included a brief survey of memorial activity in The Impact of the South African War, which he co-edited with David Omissi. ${ }^{3}$ The work carried out by the current authors forms a pilot for a much wider study of South African War commemoration in Britain, and consists of a representative comparative study designed to provide a cross-section of British responses. Memorial schemes run by a range of different communities - rural and urban, civic, religious, racial, educational and military - have been included in this survey. London and Kent were chosen because they provide a broad sample of British social, cultural, political and economic backgrounds, albeit with the admixture of the unique atmosphere of the capital city of the empire. In this regard, the study deploys the methodology used in our earlier work on Great War memorials in East London and metropolitan Essex and East Kent. ${ }^{4}$ As noted above, the intention is to expand this research into a comprehensive survey of South African War commemoration in Great Britain.

In terms of memorialisation, the conflict provides a fascinating stepping-stone to the outpouring of public commemorative effort provoked by the Great War. During the course of the nineteenth century war memorials had gradually altered in form and function. At the start of the century the overwhelming function of war memorials was to commemorate either individual battles or campaigns and usually served to glorify the commander. The struggle against Revolutionary and Napoleonic France saw major memorials erected in London, Nelson's column and Trafalgar Square, and the memorials to Wellington in the form of an equestrian statue of the general, a statue of Achilles, and the Victory Arch on Constitution Hill. By mid-century a significant shift in memorial function was beginning to occur as was seen in the wake of the Crimean War, 1854-1856. ${ }^{5}$ The conflict saw genuine engagement with the army by Britain's emerging middle-classes, many volunteering to serve in the popular cause, and this helped the army gradually to erode its highly pejorative image summed-up in Wellington's notorious phrase, 'the scum of the earth'. ${ }^{6}$ With Queen Victoria showing an immense regard for her soldiers, encapsulated in the striking of a new medal, the Victoria Cross, for supreme bravery on the battlefield, a new interest in the fate of the common soldier developed. In memorial terms this was most clearly seen in the Guards' Crimea memorial in London. Situated at the bottom end of Lower Regent 
Street at the junction with Pall Mall, it consisted of figures of ordinary guardsmen in a pose of stoic endurance, and not the lionisation of a commander. Running alongside this trend was that of the ever-increasing rituals of death and mourning in civilian life. For the middle classes especially concrete expressions of a virtuous life through a lavish funeral and a fine grave became extremely important. ${ }^{7}$ The South African War brought these two forces together.

The experience of the South African War sharpened the desire to commemorate for a number of reasons. The condition of mass literacy and a mass press was crucial. Almost every British soldier had at least basic literary skills and could write about their experiences in letters to loved ones back home. The soldiers were also accompanied by journalists, artists and illustrators and cinematographers. Modern technology was then used to give a public educated in popular patriotism and imperialism an on-going diet of stories and information. ${ }^{8}$ At the same time, the ranks of the army were swollen by large number of volunteers, particularly from the British middle classes. This gave the army, albeit for a very short space of time, a demographic much more akin to its parent population. ${ }^{9}$ Then, as with the Great War, the conflict dragged on for a lot longer than anyone initially estimated, and resulted in much higher casualties. Unlike the Great War, however, vast numbers of men died as a result of sickness rather than enemy action: 22,000 British and imperial troops died in the campaign, 16,000 from sickness, and 5,000 from enemy action. ${ }^{10}$ However death came, as in the Great War, it did so in a foreign land and therefore was not easily accessible to family and friends. Missing graves in Britain around which to mourn, remember, and celebrate, those left behind required other forms of commemoration. For these reasons many historians of commemoration in the Great War have identified the South African War as an important moment of transition summed-up in Alex King's judgement: 'Commemoration of those who died in the Boer War foreshadowed that of the Great War in many ways. ${ }^{11}$ This article marks the start of a process to explore that foreshadowing more completely.

Determining the extent to which the memorials in this sample were genuinely expressions of popular demand is very difficult. Organising committees emerged and usually claimed that they were giving concrete form to the desires felt by their own particular communities. War memorial committees legitimised their membership and role in this way, and the evidence suggests that in the vast majority of cases the committees were self-forming and self-perpetuating cliques which never sought public affirmation or legitimisation. As might be expected, leadership tended to come from those either already in a position of influence or unencumbered by other demands and therefore able to dedicate time and energy to a memorial project, which in practice usually meant those in a comfortable financial position. From each form of community the pre-existing hierarchical patterns were reinforced. In this way South African War commemoration schemes foreshadowed and influenced the pattern of Great War remembrance, for much the same tendencies were revealed when memorial schemes got under way from the summer of 1916 onwards. ${ }^{12}$

At the regimental level retired officers often took the lead in conjunction with a smattering of serving officers. In London the Royal Artillery scheme commenced with a meeting at the Royal United Service Institute in November 1902. Former Commander-in-Chief of the British army, and cousin of Queen Victoria, the Duke of Cambridge chaired the meeting, and oversaw the creation of a committee. Retired Major-General Sir George Marshall, who had commanded the Royal Artillery during the conflict, was appointed as chairman and was joined by two other majors-general and four retired colonels; three ex-officio posts were created for the Director of 
Artillery, the Inspector-General of Artillery and the Assistant Adjutant General at the War Office. ${ }^{13}$ Lord Roberts, the commander-in-chief in South Africa who masterminded the fall of the Boer capitals, also played an active role on the committee. Kent-based units used a similar structure. Although the Royal Engineers chose, in the words of Major A. T. Moore, the honorary secretary of the committee, to adopt 'a course which has been consecrated by long-usage in all non-official matters' and elect its committee at a General Meeting of the corps on 6 June 1903, the outcome, nonetheless, firmly reflected the existing command structure. ${ }^{14}$ LieutenantGeneral Sir Robert Grant, Inspector-General of Fortifications until 1898 and senior serving officer, was voted in as president with the rest of the committee comprising two major-generals and two colonels. ${ }^{15}$ The East Kent Regiment's (the Buffs) scheme was initiated at a meeting held at Howe Barracks in Canterbury on 9 May 1903.

Chaired by the Lord Lieutenant of the county, Earl Stanhope, who was supported by the colonel of the regiment, General Sir Julius Raines, acting in the capacity of vice president, the committee was, with one exception, made up of the senior commanding officers of the regiment. The only civilian member of the committee was the deputy mayor of Canterbury, Alderman W. Mason, and this was simply a matter of form as the proposed site for the memorial was on municipal land. ${ }^{16}$ Indeed, the extent to which Mason's membership was meant to be no more than a courtesy became abundantly clear when a decision had to be reached as to the memorial's exact positioning. Despite the assertion in the local press that the site had been chosen through 'negotiation between the city council and the military authorities', an examination of the council minutes tells a very different story. ${ }^{17}$ A meeting of the parks sub-committee of Canterbury city council on 10 February 1904, chaired by the mayor, recommended that the memorial should be erected on the south side of the Dane John Gardens to avoid it 'being dwarfed by the city walls'. ${ }^{18}$ However, the following week a full session of the council rejected the sub-committee's recommendation on the grounds that 'the military authorities saw objections' and the memorial was built in the shadow of the walls. ${ }^{19}$

Similar organisational structures can be found in other forms of community. The work-place memorial proposed by the London and North Western Railway for its Euston station main terminus was instigated by the chairman of the company, Lord Stalbridge, and organised by his fellow directors. ${ }^{20}$ Frederick Taylor, the Senior Physician at Guy's Hospital, co-ordinated the task of his institution's memorial committee; while a special sub-committee of the Institute of Journalists was established to oversee its plans to commemorate the war correspondents lost in South Africa. ${ }^{21}$ Two of London's leading public schools, St Paul's and Dulwich College, were led by their old boys' clubs rather than the masters or students, which reveals something of the imprint the public school system left on those who passed through it. The alumni of these institutions clearly saw themselves as retaining a deep connection with their former school and that it was important to ensure the memory of its fallen members. ${ }^{22}$ At the civic level councillors took the lead, as can be seen in the cases of Islington and Ilford, although there was some dissent in Islington, as will be shown. ${ }^{23}$ In Kent figures who straddled the military and civic worlds often dominated. Viscount Folkestone, the largest landowner in the locality and member of the Yeomanry who had served in South Africa, played an important role in the town's memorial scheme. ${ }^{24}$ In Dover the impetus was provided by the town clerk, Sir Wollaston Knocker, who commanded the $1^{\text {st }}$ Volunteer Battalion, The Buffs; while in Tonbridge, the organising committee for the memorial to be erected in the parish church of St. Peter and St. Paul included retired army tutor, John Le Fleming, who had been 
instrumental in establishing a volunteers corps in the town in $1859 .{ }^{25}$ In order to erect a London memorial to mark the sacrifices of British Jewry, a large group of British Jews was brought together. Chaired by Isidore Spielmann of the Jewish Historical Society of England, the committee also included many of the scions of Anglo-Jewry: J. Waley Cohen, Cecil Sebag-Montefiore, S.J. Solomon and Colonel A.E. Goldsmid, founder of the Jewish Lads' Brigade in $1895 .{ }^{26}$ Thus local elites established primacy over memorial schemes.

The first task of these committees was the establishment of the boundaries of the community. This was a two-fold process which involved determining who was eligible for inclusion on the memorial, and who had the right to contribute to the various schemes. Establishing eligibility for inclusion was a potentially challenging task as it touched upon issues of membership, and also forced committees to consider whether the memorial was solely for the dead or all who had served. The significance of this debate once again prefigured practice in the Great War in which communities sought to define themselves through the issue of inclusion within memorial schemes. ${ }^{27}$ Certain levels of community found the task relatively simple. All of the regimental schemes studied decided to confine their memorials to the dead alone, and they had clear records delineating their own casualties. ${ }^{28}$ (Although, as will be seen, the volunteer auxiliary forces often took a different approach.) They also gave precise instruction on contributions. In all cases serving officers and men were canvassed, but it was also usually widened to include former officers and men and relatives. ${ }^{29}$ Occasionally, decisions were taken to exclude certain groups. The Duke of Cambridge accepted the desire of relatives to make a contribution to the Royal Artillery memorial, but was adamant 'that subscriptions should be confined exclusively to members of the regiment' ${ }^{30}$ By insisting that contributions could come from the regiment alone, Cambridge cut the men from their families and made the dead the possession of the army. With death occurring so far from home in the vast majority of instances, and relatively little chance of visiting the grave, the memorial as substitute focal point of familial grief and remembrance could be undermined by such decisions. As with regimental memorials, school schemes also had relatively simple and obvious definitions for inclusion and contribution, with donations sought from current and former students and masters. ${ }^{31}$ For other distinctive communities, the clear definition of belonging sometimes complicated the issue of contribution. Having agreed that a central Jewish war memorial should be erected in the Central Synagogue, Upper Regent Street, the problem lay in making the memorial seem relevant to those outside the immediate congregation. A major form of assistance came from the support given by the Jewish charitable organisation, the Maccabean Society, which largely circumvented this potential problem. ${ }^{32}$ At the parish level decisions had to be made whether to include all residents or only the active parishioners as happened at St Jude, Kensington. ${ }^{33}$ In the case of Barkingside, contributions were sought from across the parish, but it is highly likely that the majority of the money was raised by active parishioners given that the scheme originated with members of the church.

By leaving the definitions of community to such a restricted group friction could be created over inclusion on the roll of honour. Arguments broke out over the roll in the north London borough of Islington. The Islington Daily Gazette carried letters from subscribers aggrieved that a lost loved one was deemed ineligible for the memorial. One man wrote stating his doubts over the comprehensiveness of the official roll of honour, while a publican who raised $£ 13$ through events on his premises was extremely upset that his son was ruled a resident of Stoke Newington and therefore could not be added to the memorial. ${ }^{34}$ On the eve of the unveiling the 
editorial of the local newspaper came back to this source of local strife and noted that some 'feel aggrieved that those whose names might have been recorded on the plinth have been overlooked', but defended the final decisions adding, 'the committee, however, have done their utmost to embrace the names of all who are justly entitled to the designation Islingtonians for the purposes of the Memorial'. ${ }^{35}$ These debates reveal competing concepts of identity and belonging. The guardians of the schemes wanted to ensure the honour of their districts by including only those strictly eligible, while others argued for a slightly looser, but nonetheless still passionately felt, definition of community and belonging. Both sides in the disputes saw the issue of inclusion as a matter of great pride and honour.

Organising committees also determined the listing formula. In almost every instance studied, men were listed by both name and rank. Inclusion of both elements is indicative of two underlying forces at work. By 1902 Britain was a nation increasingly aware of the middle and working classes. Indeed, the South African War can be seen as a crucial evolutionary moment for these two classes. Emerging from the shadow of the aristocracy, the middle classes, and the lower middle class in particular, made up the majority of the initial volunteers for the army, and thus often perceived themselves as the instrument of Britain's victory. ${ }^{36}$ The war validated and confirmed their importance, status and respectability. Working class volunteers had also come forward in large numbers, although historians debate the extent to which the motivation was patriotic or economic. ${ }^{37}$ Both phenomena played a part in a political scenario in which increasing uncertainty and creeping democracy created ever greater sensitivity to the issue of class. ${ }^{38}$ It also marked a point in which British practice became closer to that seen in France and Germany in which military service and the definition of citizenship were more tightly entwined, which was symbolised by widespread war commemoration and memorialisation from the late eighteenth century, but significantly accelerated by the Franco-Prussian War of 1870-1871. ${ }^{39}$ These forces made the inclusion of full rolls of honour significant expressions of class power. No longer were memorials to be dominated by the names of an aristocratic officer corps. By the same token, it was a society obsessed with hierarchy and stratification; indeed, a vital element of the middle class zeal to erect memorials was the desire to advertise its status, worth and increasing colonisation of formerly aristocratic preserves, such as the army. These movements were felt keenly in the borough of Islington. By 1901 the population of Islington stood at 335,238 making it one of the most populous of the London boroughs. ${ }^{40}$ At a parliamentary level the borough was represented by a Conservative MP, but the borough was declining in terms of its residential complexion. ${ }^{41}$ Once a smart and wealthy London suburb, the affluent areas had retreated to pockets around Highbury and Canonbury. ${ }^{42}$ Nonconformity was strong in the borough, which had created some tensions during the war as many nonconformist ministers and congregations had remained unconvinced by Britain's cause. ${ }^{43}$ The editor of the Islington Daily Gazette was therefore particularly keen to support the mayor's insistence that the memorial was for 'all classes', and implied that the bulk of the troops had come from the working and lower middle classes and recommended the scheme 'to the humbler citizens from which our soldiers... [and] the leaders of our social life'. ${ }^{44}$

In Kent the bonds between middle class status and the concept of the citizensoldier were seen strongly. For many communities the decision to persevere with the construction of a remembrance site to the conflict in South Africa was underpinned by a strong sense of collective pride in their fellow citizens who had volunteered for service. Although the justness of Britain's involvement in the war had not been, by 
any means, universally accepted at the outbreak of hostilities, the military reverses of what became known as 'Black Week' in early December 1899 had resulted in a rush of volunteers to the colours. ${ }^{45}$ Over 500 men joined the $1^{\text {st }}$ Volunteer Battalion of the Royal West Kents in 1900 and, later the same year, sufficient new recruits had presented themselves for an additional company to be formed in the regiment's $2^{\text {nd }}$ Volunteer Battalion. ${ }^{46}$ Leaders of civilian communities were keen to celebrate this display of patriotic devotion by their members and, thus, frequently forefronted the voluntary nature of service. The civic dignitaries in Dover not only determined to erect a memorial plaque to those local men who had died in the war but decided 'to combine with it a Roll of Fame in honour of those who volunteered for service and on whom the Corporation conferred the Honorary Freedom of the Borough'. ${ }^{47}$ A similar approach was adopted in Folkestone, where the decision was taken by the town council to commemorate all 'yeomen and volunteers who went to the Front', making no differentiation between those who died and those who returned. ${ }^{48}$ The strong local connections of volunteer battalions meant that they were often eager to have their active service in the war commemorated on civic as well as military sites of remembrance. Both the Second Volunteer Battalion of The Buffs and the Second Volunteer Battalion of the Royal West Kent Regiment, although included on regimental memorials in Canterbury, Rochester and Maidstone, chose to erect their own memorial tablets in the parish churches of their base towns. ${ }^{49}$ This desire to go ahead with commemorative sites, in which inclusion was so narrowly restricted, not only highlights the parochialism that underpinned the volunteer movement at the turn of the twentieth century but also hints at some of the tensions that existed between the regular and reservist forces in late-Victorian society. ${ }^{50}$

Most war memorial committees also controlled the precise form of the memorial. In almost every instance the committees were the only body to examine different proposals, and they usually made a choice without placing a shortlist or range of options before their constituencies. Remarkably little dissent or disagreement was caused by these moves. The memorial committees responsible for the schemes at Tonbridge School and in Tonbridge castle grounds both issued public calls for proposals but kept the final choices strictly in-house. ${ }^{51}$ Similarly, it was left to the colonel of The Buffs to provide precise instructions as to the form of the regimental memorial in the Dane John Gardens in Canterbury. ${ }^{52}$ The ease with which decisions about design could be reached reflected, not only the unchallenged power that these self-appointed elites wielded within their tightly delineated communities, but also the unquestioning acceptance of social stratification in the rigidly hierarchical world of early twentieth century England. Where there was debate it was often sparked by the issue of the practical utility of the chosen designs. A member of the Honourable Artillery Company asked whether the regiment would do more good by sponsoring a hospital bed as a memorial. ${ }^{53}$ A practical scheme was put into effect at Dulwich College, a prestigious London public school, and was the result of discussions between the war memorial committee run by the old boys' association and the headmaster and governors. It resulted in the adoption of a scheme to build a new library. The school magazine proclaimed the worthiness of the idea as it would provide the school with a much needed resource and form a permanent reminder of the sacrifice. ${ }^{54}$ The decision was therefore taken by a small, influential group and accepted implicitly by old Alleynians and members of the school.

Not all subscribers to memorial schemes were prepared to accept the decisionmaking processes so easily. More strident views were expressed by A.T. Gould, a resident of Islington. He implied a much deeper schism between leaders and led. A 
bad tempered letter to the Islington Daily Gazette claimed that the initial public meeting to explain the war memorial committee's ideas was a sham as it 'seemed simply to consist of a specially selected and favoured few', particular as it started at $5 \mathrm{pm}$, a time which excluded 'masters and men' still at work and suitable only for 'drones'. He went on to urge the funding of a practical scheme such as a hospital which would be especially useful to poorer people, and cited examples in Scotland. The best service of the memory of the dead was by 'sustaining the helpless ones some of our men have left behind'. ${ }^{55}$ The editorial of the Islington Daily Gazette gently mocked Gould's suggestions for their over-ambitious nature reminding readers of the great costs involved in establishing a hospital. However, this slightly facetious attitude misunderstood Gould's commitment and passion, which was shown most forcefully at the next public meeting. After listening to the opening remarks, Gould returned to his agenda, and pointedly stated his desire 'that the movement should be made as democratic as possible, and representatives of the working classes added to the committee'. Wishing to at least appear inclusive, Gould was duly elected to the committee. Howell Williams, one of Islington's representatives on the LCC, seemed to support Gould's sentiments for he called upon them to endow a nursing home or medical centre. Distinct tensions then irrupted when Gould passed a written resolution to the mayor which he asked him to read. The mayor declined to do so stating that he did not wish the meeting to descend into discord. Gould pressed his case and asked bluntly, 'Will you read the resolution?', to which the mayor equally bluntly replied 'No, I will not, for if I do, you will have the satisfaction of getting what you desire', which brought forth applause from the floor. ${ }^{56}$ Left with the sense that he was being branded a politically-motivated agitator, Gould sent his resolution to the Islington Daily Gazette:

This meeting suggests to the committee that the best method of perpetuating the memory of Islingtonians who lost their lives through the war in South Africa is to establish a permanent fund with the object of assisting the most necessitous cases among the widows and orphans created by the late lamentable war, and that (memorial) tablets be placed inside and outside public buildings. ${ }^{57}$

'I have read and read this resolution,' he added, 'and I positively cannot see anything political in it'. However, he then placed himself within a particular socio-political context by both referring to the war as 'lamentable' and concluding that his position was 'that of every workman... so I cannot but regret that the mayor refused an opportunity to the meeting to decide for or against my proposal'. ${ }^{58}$ Accusations of political motivation were clearly regarded as extremely grave insults in relation to memorial activity. Significantly, neither side in the dispute saw themselves as acting in a political manner, and were at least claiming to be oblivious to the underlying implications of their positions. Many of the Kent examples show a good deal of sensitivity over the issue of the best use of funds and whether utilitarian schemes were the most appropriate. In order to ensure that no one felt alienated by the schemes and then withheld contributions in protest, organising committees neatly circumvented this potential financial pitfall by initiating fund-raising schemes which had the dual purpose of providing relief for the dependants of men serving in South Africa and financing the construction of a commemorative site. The memorials to the townsmen of Tonbridge and the old boys of Tonbridge School, to the fallen of the county regiments, and to the volunteers from Folkestone were all entirely funded by such 
schemes. With their emphases on the immediate and practical amelioration of local distress, these initiatives were invariably enthusiastically supported. ${ }^{59}$

All of the memorials covered in this survey included some form of aesthetic, plastic expression. As might be expected, many were of traditional Victorian funerary ornamentation. The memorial was partly a surrogate headstone for dead in inaccessible graves, and the funerary form was therefore particularly apt. Memorial tablets or panels, a common form of commemoration, were erected for a range of communities. Among the military communities, the Sharpshooters, Honourable Artillery Company and Coldstream Guards used them. The Honourable Artillery Company commissioned the artist, illustrator and craftsman, Walter Crane, to design a tablet for its headquarters. Crane's work combined Arts and Crafts and Art Nouveau elements in a bronze tablet encased in a wooden frame. Significantly, the Company also took the decision to erect a small marble tablet in its church of St Botolph, Bishopsgate. The second memorial gave the Company's sacrifice public presence in a way a memorial sited in the headquarters, and inaccessible to the general public, could not. ${ }^{60}$ This was supplemented still further by financial support for an official history of the HAC during the war compiled by two of its members, Basil Williams and Erskine Childers, published by Smith, Elder and Co in $1903 .{ }^{61}$ Ilford Urban District council opted for a bronze plaque designed by a local artist. The panel depicted a typical mounted infantryman, a crucial military symbol of the South African War and a form of military experience extremely common to the volunteer civilian-soldier. As well as the Essex Coat of Arms, the national emblems of the four home nations were embossed on the corners which perhaps deliberately reflected the cosmopolitan nature of Ilford's population. ${ }^{62}$ In 1901 Ilford had a population of 41,234; during the previous ten years it had seen its numbers rise by the quickest rate and greatest number of any district in the London area. Over a quarter of these inhabitants came from outside London, and included significant Scottish and Irish communities resulting in the erection of Presbyterian and Catholic churches. ${ }^{63}$ The overwhelming majority of these migrants were from the white-collar middle classes drawn by London's economic pull. The memorial therefore neatly reflected this particular demographic mix.

Classical imagery was also much in evidence. This was seen most strongly in the school memorials. Remodelled in the nineteenth century, British public schools were dependent on the Classics believing them to be the foundation of civilised behaviour. ${ }^{64}$ In London the Merchant Taylors', Westminster and St Paul's schools all used Latin quotations or verses in their memorials. Westminster erected a plaque and invited an old boy, Professor J.S. Phillimore, a classicist, to compose a Latin inscription. Phillimore responded with a beautifully worked potted history of the role of Westminster scholars in the war. ${ }^{65}$ The use of former scholars was also seen in the St Paul's school memorial. A classical 'tempietto' was designed by F.S. Chesterton and judged by the architect, Sir Edward Poynter, who had also been at the school. The memorial consisted of a ribbed copper dome supported by seven Tuscan columns with a frieze inscription in Latin. ${ }^{66}$ Classical virtue was reinforced at the Merchant Taylors' School by the decision to record the names in their Latinised forms. These three public schools reinforced their self-perception as the inheritors and guardians of Classical values, which had been maintained by their sons in the service of Britain. Such detached and lofty expressions also reveal that these memorials had little to do with either formal or heart-felt grieving; rather, they were symbols of pride. The memorials told current scholars and the world of the glory of the institution which had moulded men who shaped the destinies of nations. 
As already noted, utilitarian schemes were largely rejected. Even where adopted, as at Dulwich College, there was the inclusion of plastic memorial forms. The new library at Dulwich was designed by Edwin Hall, an old Alleynian, in the form of an English Renaissance hall in red brick and Portland stone ${ }^{67}$ In form, Hall was playing with Tudor ideas thus reinforcing the period many Victorians took as a key moment in the transition of England into a great power. ${ }^{68}$ Hall also designed two niches for statues on the outer pillars, which contained the figures of Mars and Minerva (donated by Hall), bringing overt Classical imagery into the memorial. Other schemes included small utilitarian elements. The St Paul's 'tempietto' contained a water fountain, as did the Army Ordnance Corps and Guy's Hospital memorials. Water fountains were extremely common forms of Victorian street ornamentation, statuary and memorialisation. The provision of fresh, clean drinking water was regarded as a great public service which would cause the drinker to reflect on the qualities of those who provided it. ${ }^{69}$

As the memorials were public statements ensuring a good site was extremely important. The Royal Artillery petitioned for a site equalling its perceived importance, and was granted a plot facing Carlton House Terrace on the Mall. ${ }^{70}$ Having achieved this enormously significant location, the war memorial committee found themselves required to submit all plans to Lord Esher who was chairing the Queen Victoria memorial scheme, which included the refashioning of the Mall. As will be seen, this was not always an easy relationship and led to much intrusion into the Royal Artillery scheme. For the Jewish war memorial committee the precise location was of extreme importance and provoked much discussion. Highly sensitive to the accusation of unpatriotic or alien sympathies, the leaders of the Anglo-Jewish community were very keen to promote the Jewish role in the war. During the course of the conflict there had been anti-Semitic sentiments expressed by those who believed that the British were fighting to secure the mining rights of Jewish-owned companies. ${ }^{71}$ The war's end had seen a continued debate about the role of Jews in British society, and culminated in the Aliens Act of 1905, which was aimed mainly at curbing Jewish emigration from Eastern Europe. ${ }^{72}$ It was against this backdrop that the Jewish war memorial was debated and formed. At the initial meeting to discuss the memorial it was noted that some had 'said that the Jewish community did not do enough in the way of sending men to the South African campaign and it was right that some record should be kept of those who went to the front' ${ }^{73}$ One participant then suggested that the memorial should be placed in a Jewish cemetery, but others demurred believing it would lack visibility to the wider world. Another took exception to the idea of the memorial being public explaining that Jews had played a proud role in the war and there was no need to advertise it so overtly, and instead advocated the interior of the Central Synagogue as a perfectly good place where it could be inspected by anyone interested in Jewish affairs. Spielmann, the chair of the committee, took the opposite position. For him, an exterior site clearly proclaiming the Jewish contribution was vital, for the memorial would commemorate men who 'had not only fallen as Jews, but as English Jews, and, therefore, the exterior of the building did not seem improper' ${ }^{74} \mathrm{He}$ added that if it was not erected at the Central Synagogue, then it might well be placed in an East London synagogue. Spielmann's remarks reveal a pronounced concern about the nature of the Jewish community. The East End was home to a significant number of poor, unassimilated Eastern European Jews and formed the main target of anti-Semitic comment in Britain. He was therefore highly sensitive to the idea that the memorial might be located in the 'wrong' sort of synagogue. For Spielmann, it was important that assimilated, affluent, respectable, anglicised Jewry make the public statement. 
British Jews were to be caught in precisely the same bind after the Great War when the same arguments were rehearsed in an almost identical fashion. ${ }^{75}$

For the committee of the Royal Artillery, the key issue of impressing the importance of their worth and role was expressed in their desire to erect memorials of the finest quality making a significant aesthetic statement in the process. Artistic value was regarded as an important signifier of the memorial's worth. Given a site in the Mall, the Royal Artillery committee was also extremely keen to provide a memorial grand in drama and aesthetic quality. Accordingly, an established sculptor was approached, W.R. Colton, who commenced work on designs. ${ }^{76}$ The site allocated to the Royal Artillery drew in King Edward VII, as it would form an integral part of the Mall widening and Victoria memorial scheme, on which he was consulted at every stage by the project's chair, Lord Esher. Esher's aesthetic tastes were immediately disturbed by the preliminary designs, and in the process he cut to the heart of the memorial's function. Recognising the importance of every member of the regiment, the Royal Artillery committee wanted to include panels giving the full roll of honour revealing an understanding of the equality of sacrifice. For Esher the name panels were abhorrent. He wrote to the Secretary of the Office of Works: 'one thing is absolutely hideous, which is the idea of inscribing the long list of names [underlined in the original] on the memorial... It would be turning St James' Park into Kensal Green'. ${ }^{77}$ Esher clearly believed the listing of names was inappropriate in this public space, and was instead the preserve of a cemetery - hence the reference to one of London's great Victorian necropoli, Kensal Green. However, the King was much less worried by this consideration, and gave broad support to the plan, but requested full designs of the proposed memorial before giving final consent. ${ }^{78}$ This produced a change of heart in Esher who now insisted that the name panels should be moved to the bottom of the memorial. Such a judgement shows that Esher still believed that it was inappropriate to allow the roll of honour to dominate the memorial. ${ }^{79}$ Colton duly amended his plans, but this did not resolve the matter. Sir Shomberg McDonnell, the Secretary to the Office of Works, was concerned by the sketches of the horse, representing the spirit of war, due to crown the memorial. He wrote to Colton outlining his belief that the King would not approve the current designs: 'In fact without wishing to urge upon you the design of a conventional horse it is quite certain that only a perfect horse is likely to meet His Majesty's approval. ${ }^{80}$ Colton was content to oblige and confirmed the changes he had made to bring the designs into line with the requests. ${ }^{81}$ However, the final design of the memorial was still not set. In December 1906, Colton requested permission to exhibit a model of the memorial at the Royal Academy with a notice that the design had been approved by the King. McDonnell agreed to the exhibition of the model, but refused permission to advertise the King's approval, as it had not yet been formally agreed. ${ }^{82}$ Somewhat amazingly, the issue made no progress over the next three years. The precise reasons for this delay are obscure, but were probably caused by Colton's commitments to other projects. A model was ready for exhibition in 1909, but still caused disquiet. By this time McDonnell's patience with Colton was severely stretched, as was that of Lord Roberts, honorary chair of the Royal Artillery memorial committee, and McDonnell was using Thomas Brock of the Royal Academy as an intermediary to influence Colton's designs. In one letter to Brock, McDonnell took the opportunity to vent his frustrations:

Mr Colton, for some reason of his own which he endeavoured to describe, but which I confess I am not quite able to fathom, has placed the right wing of the figure at a 
curious angle: the effect is to make the wing droop over the neck of the horse, and to give the impression that Peace has sustained a wound in that member, and is unable to keep it at the same angle as the left wing.

I feel that this must be remedied, and the two wings placed at the same angle: otherwise the symmetry of the monument will, I think, be seriously impaired, and it may possibly appear a little absurd, which would be unfortunate in the highest degree. ${ }^{83}$

This time, Colton seems to have taken everything to heart and produced a fresh model. McDonnell travelled to Colton's studios near High Wycombe to examine it, and found 'the result extremely good', as he told Esher by letter. However, he still had a problem with the angle of Peace's left wing. The intention was that it should cover the horse conveying the impression that Peace had tamed War. 'This idea may be excellent, but the result is grotesque: it gives the impression that somebody has shot at the angel and tipped it in the wing'. McDonnell confirmed that Colton 'is a charming man, and his work is delightful; but he is rather inclined to be obstinate about it'; he therefore requested Esher to visit Colton personally in order to press the case. ${ }^{84}$ By the autumn the amendments had been made, and the memorial was finally given royal consent. ${ }^{85}$

Having completed fund-raising in 1906, explaining the delay to both the regiment and the general public was extremely difficult and embarrassing. Lord Roberts had been anxious to exhibit full designs of the memorial to contributors in 1906, but had not been able to do so. ${ }^{86}$ When the memorial was finally unveiled in July 1910, The Times noted that the delay in completion was due to debates over siting. The source of this information is unclear, but it was a tactful excuse to cover the catalogue of revisions. ${ }^{87}$ Rather sadly, the memorial was not then considered an unqualified success. F.W. Speight of the Society for the Protection of Ancient Buildings complained that the memorial had not been centred on the Duke of York's steps on the opposite side of the Mall meaning that it looked unbalanced to anyone descending the steps. ${ }^{88}$ Another correspondent to The Times drew attention to the fact that the names were placed too low down, and overheard two spectators at the unveiling 'disputing as to whether the wings on the monument belonged to the "horse or the lady." I shared their doubts. ${ }^{89}$ Two more complaints were then received on the position of the names. Both correspondents implied that the hapless Colton was to blame, when in fact he had originally proposed a much more prominent siting of the name panels. ${ }^{90}$ The convoluted gestation of the Royal Artillery memorial reveals the tensions inherent in a public memorial. Because of its location, it was expected to conform to a different aesthetic from that originally desired by its instigators.

However, the Royal Artillery committee was never prepared to forego the prestigious site in order to regain closer control of its form and function.

The equally ambitious scheme of the Royal Engineers at their Chatham headquarters also had some elements of controversy despite the close control exerted over the scheme by a small group of influential officers. The process revealed that even in the strictly stratified and disciplined environment of the military, disputes could break out if it was felt that traditional channels of communication and forums for discussion had been subverted. This was especially the case if these latter were the preserve of retired officers for whom a fierce loyalty to their former regiments was frequently combined with an unwavering advocacy of the old ways of doing things. For the Royal Engineers, the first hint that all was not well with the corps' memorialisation process was to come from a retired colonel, E. Lloyd. In a letter to 
the memorial committee, he expressed his concern that decisions had been taken without the convening of a general meeting of the officers, 'a course that has been consecrated by long-usage in all non-official matters concerning the corps. ${ }^{91}$ In fact, the committee could have been forgiven for assuming that such an informal channel for validation need not have applied in this case, for the scheme had been instigated by no less a person than Lord Kitchener, Lord Robert's replacement as commanderin-chief of the British forces in South Africa. In May 1902, Kitchener, who had been commissioned into the Royal Engineers in 1871, had written to the commandant of the corps at Chatham, Sir T. Fraser, with the offer of 'four bronze statues of Boers and four bas-reliefs for use in a war memorial to the fallen'. For good measure he had enclosed a detailed sketch of his proposal. ${ }^{92}$ Unsurprisingly, Fraser had been quick to accept the offer and a memorial committee meeting in October 1902, chaired by Sir Robert Harrison, the Inspector General of Fortifications, had unanimously agreed to press ahead with the plan. ${ }^{93}$ Although Colonel Lloyd's protest, which had been prompted by an article outlining the scheme in the regimental magazine, was soon followed by others, the committee 'decided to inform the correspondents that they intended to continue with the memorial nonetheless'. ${ }^{94}$ It was only when Field Marshal Sir John Simmons, former Inspector-General of Fortifications from 18751880 and governor of Malta until his retirement in 1888, added his name to the list of complainants that the committee eventually caved in and resolved 'to defer any further action until a General Meeting of the corps can be held' ${ }^{95}$ Predictably, the first resolution that this general meeting passed was to elect an entirely new committee.

Yet, though procedural irregularities undoubtedly antagonised many retired officers, at the root of the Royal Engineers' dispute lay much graver concerns over the form that the corps' memory site should take. As Alex King has shown in his survey of commemoration in the aftermath of the First World War, choice of design was considered to be all-important in an age when it was generally believed that iconographical symbolism was fixed. ${ }^{96}$ The Boer statues and bas-reliefs had originally been intended as the focal points for a monument in honour of Paul Kruger, the former president of the Transvaal. The pieces had been embargoed at the outbreak of war and eventually donated to Kitchener who, as noted above, subsequently offered them to the Royal Engineers' memorial committee. Although, in many ways, Kitchener's offer can be securely sited in the classic tradition of the triumphal, the contentious symbolism of the statuary must have rung some alarm bells even with the original memorial committee members. ${ }^{97}$ Indeed, their awareness of the sensitive nature of the proposal can be discerned from their immediate response. Despite insisting that the pieces should be viewed as 'impersonal' and 'works of art', they, nevertheless, decided that a bas-relief depicting the peace conference at McNeill's Farm after the British army's ignominious defeat at the battle of Majuba Hill in the First Boer War was a step too far and should be replaced by a 'plaque recording Lord Kitchener's gift of the bronzes' ${ }^{98}$ That this nod towards conciliation would prove to be far less than was going to be necessary to stem the tide of criticism that the committee would eventually face over the inclusion of such controversial images is hardly surprising, but that it should ever have been considered sufficient does provide us with a fascinating insight into the contested meaning of the war in Britain at the conclusion of hostilities.

Anti-Boer feeling, which was an inevitable consequence of the brutality of war for British combatants and which had been fuelled domestically by the 'yellow press', sat uneasily with the assimilation of the Boer Republics into a federated British South Africa by the Treaty of Vereeniging. ${ }^{99}$ Although nearly all those present at the general 
meeting of the Royal Engineers on 6 June 1903 were in agreement that the original plans of the memorial committee to include the Boer statues and bas-reliefs on the corps' memory site should be abandoned, there were still heated exchanges when it came to providing a rationale for this stance. Major M. Hildebrand, a retired RE officer, clearly articulated the view that consideration of Boer sensibilities had to take precedence when it came to commemorating the war. In a letter sent to the editor of the Royal Engineers' journal and read out at the meeting, he made plain the repercussions that pressing ahead with the original plan would have:

Having lately been in the Transvaal, I learned that the idea [of using the statues and bas-reliefs on the RE monument] had become known to the Boers, to whom, I was assured, it would give immense annoyance and pain. My informant, who broached the subject with me asked if it were true, which he did not until then believe, had exceptional opportunities of learning the Boer sentiments, though himself a supporter of the new order of things. He said to make such use of what had been intended for Mr. Kruger's statue would cause the keenest feeling of resentment amongst our new fellow subjects. 100

Major-General Sir Elliott Wood, who had served as Engineer-in Chief during the war and was a member of the original memorial committee, was quick to voice his support for this line of reasoning. Having been responsible for drawing up the original sketchplan of Kitchener's scheme, he was clearly keen to distance himself from what had turned out to be a contentious and manifestly unpopular proposal. The choice of design was, he insisted, 'a very important question... for it might become more than a corps matter; it might go beyond this and affect the army and perhaps the country generally, if we were to give offence to our new fellow subjects. ${ }^{101}$ For two retired senior officers, however, the memory of the human cost of the recent fighting was still too fresh for consideration of such political niceties to take priority. Arguing that it was first important 'to clear up our own views before we consider those of other people', Lieutenant-General Sir Robert Grant urged those assembled to 'remember that it was through what we hold to be [the Boers'] mistaken views and their mistaken actions that we lost the officers and men to whom we wish to erect the memorial'. ${ }^{102}$ General Sir James Browne, a former Colonel Commandant of the corps, was prepared to go one step further when apportioning blame. In a letter read out at the meeting on his behalf, he maintained that to use such 'undesirable images would be a monument to bad taste, never to be effaced', for the statues 'were made to honour Mr. Kruger, the man of all others in this world responsible for the deaths of those we wish to honour.' 103

An interesting argument to bolster further the case against the original proposal was presented by Sir Thomas Gallway, who had recently succeeded Sir Richard Harrison as Inspector General of Fortifications. Insisting that the minutes should record his 'strong protest' against Kitchener's scheme on the grounds that the statues 'represent an armed enemy', Gallway raised the moral stakes by arguing that, before any decision could be reached, the meeting must first 'consider the feelings of the relatives of our gallant dead'. ${ }^{104}$ Major J. Winn, a member of the original war memorial committee, although differing on the nature of the views held by the bereaved, was still equally adamant that they merited special consideration. His attitude had, he said, 'hardened' against using the statues as the result of a letter he had recently received from the father of one of the fallen: 
I am thinking of a man who in a letter said he thought that, if the Boers would consider it to be a bad thing for the figures to be used, it ought not to be done. Knowing that man lost a son in the war, I feel more strongly that his views should carry weight on the subject.' 105

In advancing their own viewpoints by privileging the opinions of a group which fell outside the bounds of the military community, both Winn and Gallway were, inadvertently, raising wider questions surrounding the ownership of the memorial. Only four months earlier members of the organising committee had made abundantly clear, by the grudging manner in which they had accepted an unsolicited contribution to the memorial fund from a bereaved mother, that the construction of a memory site should be a matter for the corps alone. ${ }^{106}$ However, aware that such an exclusive approach could not be sustained if a climate developed where iconographical symbolism and, by extension, the very meaning of the war were contested, the meeting unanimously resolved to elect a new committee with instructions to start the process afresh. The threat of any further dissent was subsequently averted by devolving the question of form to the professional care of an established architect, Ingress Bell. ${ }^{107}$ His decision to opt for a triumphal arch, to mirror the Crimean Arch erected at the corps' headquarters in Brompton in the 1860s, was reassuringly uncontroversial and the project proceeded to completion without further hitches. ${ }^{108}$ The gestation of the Royal Engineers' memorial reveals fully the political and moral value attached to public art and architecture in Victorian and Edwardian Britain, and how it could provoke intense debate.

Civic authorities were also capable of stirring-up controversy over the precise form and location of their memorials, as can be seen in the case of Islington and Dover. The borough of Islington wanted an impressive piece of statuary. As has been noted, there was dissent from some quarters over form, but the majority of the committee held firm for an aesthetic, plastic memorial. Designs were invited, but from relatively unknown or emerging artists in order to contain costs; however, no decision was taken throughout the whole of 1904. It was not until May 1905 that a contract was formally signed with Bertram Mackennal, a sculptor who was rapidly cementing his reputation, for a figure of Glory holding a figurine of Victory in her right hand and a laurel wreath in her left. ${ }^{109}$ The committee did not, therefore, opt for anything overtly funereal or connected with grief: the dominant iconographic message was the glory won for the borough by the sacrifice of its inhabitants. The appeal for funds was launched in the summer of 1903 nearly two years before the nature of the memorial was finalised, but a year after the end of the war. Launching the scheme so late caused some to doubt whether the scheme was already doomed. An editorial in the Islington Daily Gazette bemoaned the fact that the mayor's call to action was too late, and many had now shamefully forgotten the sacrifice made by their fellow Islingtonians. ${ }^{110}$ When the fund was launched in September it met with a desultory response, which was hardly surprising given the lack of advanced publicity over the initial public meeting, the subsequent controversy over the composition of the committee, and the complete lack of any public announcement as to the precise nature of the scheme. In effect, the Islington war memorial committee asked people to subscribe to a void, and expected them to continue doing so. As has been noted, the committee then made no formal decision until the spring of 1905, and only exhibited a sketch of the memorial in May 1905, just two months before the unveiling. ${ }^{111}$ Unsurprisingly, the local newspaper carried many comments on the very slow progress of the memorial fund. The target was vaguely set at between $£ 700$ and $£ 800$, 
and this was thought easily achievable with a population of 345,000 , but only $£ 370$ was collected by October $1903 .{ }^{112}$ With little clarity emerging from the committee, the collection inched forward reaching $£ 728$ by the time the memorial was unveiled in July 1905. A similar situation unfolded in Dover. Having already tested the charitable reserves of the local populace with public appeals to finance the South African War Fund in January 1900 and the Queen Victoria memorial project in June of the following year, the local civic elite managed to compound the financial difficulties facing what was the port's third publicly-funded scheme in four years by adopting an approach which was, at one and the same time, precise in its financial ambition and vague in its conceptual realisation. ${ }^{113}$ The press release for the launch of the scheme best illustrates this point: 'It is the intention of the civic authorities to raise an indoor memorial in St Mary's church, at a cost of $£ 200$, and an outdoor monument, at upwards of $£ 300$, to the memory of the men who fell in the recent war in South Africa. The type of memorials will depend on the amount of money raised and the wishes of the subscribers.' 114 In effect, Dovorians were being asked to contribute to two costly schemes while being given no indication of the final form either would take. Unsurprisingly, the scheme did not elicit an enthusiastic response and it was not until nearly a decade after the war had finished, by which time the financial shortfall had resulted in the outdoor monument being abandoned, that a commemorative tablet in St. Mary's church was unveiled. ${ }^{115}$ Successfully raising subscriptions for memorial schemes depended in part on making a clear appeal to the relevant community based on an equally clear objective. Subscribers wanted to know what they were contributing towards and delays either in deciding a final form or in explaining it to the public often caused difficulties for fund-raisers. The civic projects of Islington and Dover reveal this problem most fully.

Other communities found it easier to raise large sums. The Dulwich College scheme was marked by the speed with which a form was determined and explained, and then backed up by the wealth it could draw from its old boys. This ensured a flow of funds from former scholars in locations as far afield as India and Ceylon, and illustrious old boys such as the Bishops of Rochester and Calcutta and two knights of the realm. The subscriptions lists also reveal nine people making at least two separate donations, and at least one making three. Such subscribers could also afford lavish sums with four donations of $£ 100$ and two of $£ 50$. The $£ 3000$ sum was thus reached by the time of unveiling in July $1903 .{ }^{116}$ The Royal Artillery drew upon a wide range of current and former members reaching down to individual batteries, some of which subscribed $£ 100$ between them, and the $£ 7000$ target was reached by the winter of 1905 , although $£ 850$ was needed from the Victoria memorial scheme to pay for the erection. ${ }^{117}$

The didactic messages of memorials were reinforced at unveiling ceremonies which were used to promote a range of corporate messages about each form of community. At the military level it was often taken as an opportunity to remind those present that the regiment had lived up to its traditions and inheritance with an equal stress on the concepts of duty and the nobility of self-sacrifice. Lieutenant-General Robert Baden-Powell, the hero of Mafeking, emphasised the path of duty in flowing rhetoric when unveiling the Sharpshooters' memorial in St Martin's-in-the-Fields, and in the process made explicit the link between duty-done and the memorial's function as a didactic guide to future generations:

The Sharpshooters had had as a regiment but a short life, but in the four years of their existence they had made a history for themselves such as any other regiment might be 
proud of by the self-sacrifice and devotion to duty they showed when in South Africa. They went from their homes when their country needed them; they gave up their ordinary pursuits and their connections here, and left this busy city to help their country's cause on the veldt... It was needless for them to put up monuments to commemorate what they had done. Their own work in doing what they did for the Empire was sufficient monument in itself; but it was as well to have with them a tangible record, so that their names and deeds might not be forgotten, and, more especially that their example might dwell among them for future generations to follow. The highest praise that they could give those men was that they placed their duty before all. The guiding principle for all men, of whatever rank they were in life, whether they were fighting men or working men, was to carry out the motto of placing their duty before all and, as those men did, to sacrifice their own inclinations, their own personal feelings and ambitions, and their own lives if necessary, for their fellow men. He therefore unveiled that monument to men who did their duty. ${ }^{118}$

Stressing the importance of the memorials as symbols of duty and selfsacrifice which should guide others in the conduct of their lives was both an implicit and explicit element of virtually every unveiling ceremony, and was a conformist message particularly aimed at the young. The boys present at the Merchant Taylors' school memorial ceremony were told that those "who had given their lives for King and Country should serve to guide the school in the path of duty and self-sacrifice'. ${ }^{119}$ The mayor of Canterbury was insistent that the pupils of Simon Langton Boys' School should be 'proud of those boys who served in time of need' and should regard the names listed on the commemorative tablet as 'an incentive...to do likewise when the occasion presented itself' ${ }^{120}$ In a sermon delivered after the unveiling of the memorial window in Tonbridge School chapel, the Bishop of Kensington, an Old Tonbridgian, reminded the pupils present that the reason why the fallen had sacrificed their lives 'was written on their graves; it was for King and Country'. ${ }^{121} \mathrm{He}$ then proceeded to outline and exemplify for his young audience, in a passage redolent with the images of Newbolt's Vitai Lampada, the conduct and qualities expected of the products of the Edwardian public school system:

The young officer who died with the colours for his shroud which he tried to save, the man in the bridge of the warship who refused to leave the vessel, and went down, saluting as he went, and the boy who forfeited popularity because the sense of duty was rooted in his soul; were these things hard? Or did it tell them of the most pathetic feature, of the magic power, the influence and the strength of character which duty produced? ${ }^{122}$

Similarly, the Royal Fusiliers' memorial was to act 'as a bright example to those who came after - a bright example of devotion, loyalty and patriotism to the young men of the country'. ${ }^{123}$

If calls to patriotic service were to have any public resonance, then it was vital that the cause in which the sacrifices had been made should be seen as pure. The contentious nature of the memory of the South African War, both in terms of motivation and conduct, encouraged many officiating dignitaries to revisit old debates in an attempt to set the imperial record straight. Although, in Kent it should also be noted that location may well have had a part to play in this trend for, with villa Toryism holding sway in the west of the county and rural Conservatism dominant in the east, speechmakers could be relatively secure that politically conformist messages 
in support of Britain's imperial role would find receptive audiences. ${ }^{124}$ Lord Harris, who as honorary colonel of the Royal East Kent Mounted Rifles had successfully encouraged eleven of his men to volunteer for active service as early as November 1899, was determined that any lingering doubts over the justness of Britain's involvement in the recent war should not be allowed to cloud the minds of the pupils of Simon Langton Boys' School. He informed his young audience at the unveiling of the memorial tablet in honour of the Old Langtonians who had served in the war that,

Just as the Boers have been held up as great patriots and as gallant defenders of their land, so it was perfectly legitimate for them, who were doing honour to those, many of whom were volunteers, to remember that the service they gave was just as much in defence of their country as the service given by the Boers in defence of the Transvaal. Because for a long time the action was fought, not on Transvaal territory, not on the Orange River, but on British territory. In fact, it was to force back that invasion that many of those men volunteered. ${ }^{125}$

The imperative of Imperial defence was also a key theme in the dedication addresses at both commemoration ceremonies in Tonbridge. The congregation attending the civil service at the parish church of St. Peter and St. Paul in April 1904 was told that the fallen had 'forfeited their lives for the honour and integrity of the Empire', while the message for those assembled for the unveiling of the combined civic and school monument in the castle grounds two months later was that the sacrifices of war had 'helped save South Africa for the Empire'. ${ }^{126}$ Indeed, the willingness of members of the memorial committee for the combined scheme to confront the contested memory of the conflict head-on can be seen in their choice of Sir Redvers Buller as officiating dignitary. In offering a vote of thanks after the unveiling, Charles Fitch Kemp, the president of Tonbridge Central Conservative Association, dismissed public criticisms of Buller's military record by asserting that, 'Sir Redvers had been a gallant soldier and above all he had proved himself to be one of the kindest and best of generals'. ${ }^{127}$ As a further endorsement of Buller's standing, a bereaved mother and three war veterans were then 'given the honour of shaking hands with the General'. ${ }^{128}$

Institutions also took the opportunity to advertise their worth to the wider community. Honour deriving from the achievements of community members was a particularly common theme in schools. The headmaster of Simon Langton Boys' School in Canterbury, Mr P. Winn, was quick to make a connection between the war record of the old boys and the school's ethos. Having unveiled the memorial plaque to the thirty-one Old Langtonians who had served in the war, he told the assembled pupils that, 'This is, I think, a large number for a school of this size. We have never had a desire to uphold the warlike spirit, but we have most strongly inculcated patriotism and we think we are justified in feeling pride that so many of our old boys were ready to respond to their country's call. ${ }^{129}$ Indeed, for Winn the memory site not only validated the schools' guiding principles but added another layer to the traditions that underpinned them. 'It would', he said, 'have its place among the honours' records of the school which are helping to make history for us'. ${ }^{130}$ The unveiling of the memorial window in the chapel at Tonbridge School was equally suffused with institutional pride. The Lord Lieutenant of Kent, the Marquess of Camden, told the pupils present at the unveiling ceremony that he 'hoped the window would remind them, and those who came after them, to uphold the traditions of their school, which held so high a place among the public schools of England' ${ }^{131}$ Dulwich College turned its unveiling into a celebration of the school rather than the dead. The ceremony was 
held on the school festival of Founder's Day and focused mainly on the excellence of the new library, which, it was said, was a tribute to the old Alleynians affection for their former home. ${ }^{132}$ For the scions of Anglo-Jewry it was a crucial opportunity to promote an image of loyalty and conformity. Isidore Spielmann informed the congregation at the Central Synagogue of the memorial's meaning: 'This memorial stands here in eloquent testimony to the fact that British Jews are inspired by a love of King and Country no less enthusiastic and no less devoted than that which animates their fellow-subjects.' Following on, the Chief Rabbi stated that 'surely England deserves that we, her Jewish children, should gladly live and die for her... since here, as in no other empire in the whole world, there breathes a passionate love for freedom'. ${ }^{133}$ By using the ceremonies to stress wider points about communities the focus on the dead could be lost. This was most clearly seen in the unveiling of the Islington war memorial. The local newspaper's coverage of the event records speech after speech stressing the glory of Islington and the beauty of its memorial. Civic pride was very much the tenor of the day, and the dead were almost incidental to the occasion. Much the same spirit can be detected in Kent where for many local inhabitants the dedication of a remembrance site to their community's fallen seems to have played a poor second to the thrill of receiving a visit from a figure of national prominence. The Dover Express neatly caught the sense of breathless excitement that greeted Field Marshal Lord Roberts on his arrival to unveil the port's memorial in 1912: 'every eye was strained to catch a glimpse of the hero of a hundred fights. It would, indeed, have been a strong-hearted Briton who did not experience a thrill of emotion at that moment'. ${ }^{134}$ The presence of Sir John French, Sir Redvers Buller and Lord Roberts at unveiling ceremonies in Folkestone, Tonbridge and Canterbury respectively received similar coverage. In the Medway towns of Rochester, Gillingham and Chatham, the determination of the local populace to use the King's attendance at the unveiling of the Royal Engineers' memorial as an excuse to turn the day into a patriotic carnival was vividly captured by the Chatham News: 'Flags! Flags! Flags! Flags here, flags there, flags everywhere - nothing but flags of all colours, all sizes and all descriptions, the whole combining to make a bright display.' 135

Frequently the wider programme for the day of an unveiling ceremony signposted the lighter tone of the occasion. Once the King had performed his official duties for the Royal Engineers, he was invited to lunch in the officers' mess followed by a programme of popular music. Similarly, for the warrant officers and noncommissioned officers of the corps, the formal business of the day soon gave way to regimental sociability. A 'reunion lunch for past and present members' was held after the unveiling followed by a smoking concert at which there was 'an excellent programme including over thirty items, made up of toasts, recitations, songs and instrumental solos'. ${ }^{136}$ In Tonbridge, Sir Redvers Buller's visit to unveil the civic war memorial was carefully timed to coincide with a county cricket match. Charles Fitch Kemp, a member of the memorial committee and president of Kent County Cricket Club, made it abundantly clear which of the two events he considered to be the main business of the day. At the post-unveiling lunch held in Buller's honour at the county cricket ground, he told his fellow diners that, 'He did not propose to say one word about military affairs. He rather greeted [Buller] as a country gentleman who had come down to meet his neighbours and friends on the occasion of a county cricket match. ${ }^{137}$

This tone marks a significant difference to Great War commemoration in which the concentration on the grief, mourning and the fate of the dead was much 
more pronounced. Further, unlike during the Great War, in no memorial covered in this survey was the ultimate symbol of Christian sacrifice, the cross, an overt or main element in the scheme. It implies that the dead were often commemorated on a level beyond that of the immediate family and its needs. Only memorials unveiled for particular individuals attempted to provide comfort and reassurance to the bereaved. The wealthy family of Lieutenant Bertie Moeller, residents of the bourgeois London suburb of Belsize Park, paid for a lavish memorial to him in their parish church. The unveiling was carried out by the Bishop of Kensington (which also reveals the family's social standing) and his remarks were firmly designed to provide solace to Moeller's grieving parents and family:

In this case Lieutenant Moeller had not died in vain. His country's greatness was being built-up by the death of her sons, and the shutting of the doors of their young lives, meant probably the swinging back of the door of South Africa for fuller civilisation and Christianity. By his death, too, Lieutenant Moeller had shown the beauty of self-sacrifice; the reality of life to come was forced upon one by it, and had established a stronger and more tender bond of brotherhood, and had sealed and cemented regimental cords of sympathy. That screen would stand, not to tell of what was premature and untimely, but that in the greatest tragedies of life God did see one thing over and against another. ${ }^{138}$

Moeller's former commanding officer, Lieutenant-Colonel L.R.C. Boyle, took a similar line reassuring the bereaved that: 'He was a dutiful, affectionate son, a kind brother, and a warm-hearted and true comrade. Well might his family and his country be proud of such a son!' ${ }^{139}$ However, similar comments appear to have been rarely used at other ceremonies. Among the few that did was the Reverend W.S. LachSzyrma at Holy Trinity, Barkingside, a rural parish on the fringes of East London. He referred to the dead as Christian martyrs and implied their joyful resurrection, which was a message designed to comfort those in mourning. ${ }^{140}$ When the Bishop of Kensington unveiled the Honourable Artillery Company tablet in St Botolph, Bishopsgate, he used terms that would become familiar in the Great War: 'They were not dead; they were more alive than we, and, in heaven, were partaking of that fuller and richer life with which nothing on earth could compare. ${ }^{, 141}$ The relative paucity of such comments and rarity with which the cross was used as a symbol compared with the Great War may also reflect the generally lower emotional temperature experienced during the South African War, aside from a few major outbursts such as Mafeking night. Unlike the Great War, the South African War did not lend itself to the idea that the whole of the civilised world was in danger. The thundering sermons of Bishop A.F. Winnington-Ingram and the widespread use of apocalyptic and eschatological imagery during the Great War made the cross, as the symbol of Christian redemption, much more applicable and ubiquitous ${ }^{142}$

South African War memorials in London and Kent were therefore erected by a broad range of communities. The memorial forms were remarkably consistent with Victorian funerary practice, as were their iconographic messages, reinforced during unveiling ceremonies, which were always conformist and reassuring. As noted, messages and symbols aimed squarely at those grieving were rare, and often the dead were used by the wider communities to which they belonged to make a range of other statements. ${ }^{143}$ Not all memorial schemes were accepted with universal approval, and dissent was expressed. As in the aftermath of the Great War, certain pre-requisites for a successful war memorial scheme emerged: leadership had to be firm and clear, the 
fund-raising target needed to be set early, and crucially, it had to be realistic and within the means of the community, and the form of the memorial had to be advertised quickly and effectively. Islington and Dover failed to do this and their civic pride took a knock in the protracted gestation which followed. Such pitfalls were repeated by a significant number of communities in the wake of the Great War. The memorialising process that followed the South African war was therefore rich and complex, and this sample reveals the emergence of many of the issues that were to become dominant in the Great War. The next task is to widen the scope of the survey to throw further light on the process.

\footnotetext{
${ }^{1}$ See, for example, Ken Inglis, Sacred Places. War memorials in the Australian landscape (Melbourne: Melbourne University Press, 1998); Chris Maclean and Jock Phillips, The Sorrow and the Pride. New Zealand war memorials (Wellington: GP Books,1990)

${ }^{2}$ Martin Saunton, 'Boer War memorials in Ireland' in Donal P. McCracken (ed), Ireland and South Africa in Modern Times, Vol. 3, 1996 (Southern African-Irish Studies, 1996) pp. 290-304; Edward M. Spiers, The Scottish Soldier and Empire, 1854-1902 (Edinburgh: Edinburgh University Press, 2006) pp. 204-206

${ }^{3}$ David Omissi and Andrew S. Thompson, The Impact of the South African War (Basingstoke: Palgrave, 2002) pp. 99-123

${ }^{4}$ Mark Connelly, The Great War. Memory and ritual (Woodbridge: Boydell and Brewer, 2002); Peter Donaldson, ,Ritual and Remembrance, The Memorialisation of the Great War in East Kent, (Newcastle: Cambridge Scholars Press, 2006)

${ }^{5}$ For further discussion on this shift in emphasis see Alan Borg, War Memorials. From antiquity to the present (London: Leo Cooper, 1991) pp. 104-124

${ }^{6}$ See Olive Anderson, A Liberal State at War. English politics and economics during the Crimean War (London: Macmillan, 1967)

${ }^{7}$ See Pat Jalland, Death in the Victorian Family (Oxford: Oxford University Press, 1996)

${ }^{8}$ See John Gooch (ed), The Boer War. Direction, experience and image (London: Frank Cass, 2000) pp. $187-244$

${ }^{9}$ See M.D. Blanch, 'British Society and the War' in Peter Warwick (ed), The South African War. The Anglo-Boer War, 1899-1902 (Harlow: Longman, 1980) pp. 186-209

${ }^{10}$ Figures given in Thomas Pakenham, The Boer War (London: Weidenfeld and Nicolson, 1979) p. 572

${ }^{11}$ Alex King, Memorials of the Great War in Britain (Oxford: Berg, 1998) p. 42

${ }^{12}$ See Connelly, The Great War, p. 26

${ }^{13}$ The Times, 9 July 1910

${ }^{14}$ Royal Engineers Museum (REM), RO270, Royal Engineers War Memorial Committee Book, Corps meeting minutes, 6 June 1903

${ }^{15}$ However, as will be seen later, this committee was only formed after a lengthy and relatively protracted dispute

${ }^{16}$ KGCP, 9 May 1903

${ }^{17}$ Ibid., 4 June 1904

${ }^{18}$ Canterbury Cathedral Archives (CCA), CC/AC23, Parks Committee, minutes, 10 February 1904

${ }^{19}$ CCA, CC/AC/23/1, Canterbury City Council, minutes, 17 February 1904

${ }^{20}$ The Times, 24 April 1903

${ }^{21}$ The Times, 5 November 1902; 16 January 1905

${ }^{22}$ Dulwich College Archive, The Alleynian, Vol. XXIX, No. 211, June 1901, p. 163; Michael F.J. McDonnell, A History of St Paul's School (London: Chapman and Hall, 1909) p. 445. (Many thanks are due to Callista Lucy, Archivist to Dulwich College, for making the records available for inspection.)

${ }^{23}$ Metropolitan Borough of Islington, Council Minutes, Vol. IV, 1 April 1903 - 31 March 1904, 3 July 1903 p. 152; Islington Daily Gazette, 17 July 1905 (hereafter IDG); The Times, 27 November 1902; Ilford Urban District Council Minutes, Vol. V, March - September 1904, 24 July 1904, p. 573; Ilford Recorder, 2 September 1904 (hereafter $I R$ )

${ }^{24}$ Folkestone Express, 23 April 1904 (Hereafter FE). Indeed, the name of Viscount Folkestone, who on the death of his father had become Lord Radnor, appears at the head of the Roll of Honour.
} 
${ }^{25}$ East Kent Archives (EKA), Do/CA17/1/17, South African Memorial Committee, minutes, 6 May 1904; TFP, 15 April 1904; A.H. Neve, The Tonbridge of Yesterday (Tonbridge: Tonbridge Free Press, 1933) p. 195

${ }^{26}$ Jewish Chronicle, 24 March 1905

${ }^{27}$ See Connelly, The Great War, pp. 36-48, 75-97, 98-135

${ }^{28}$ TNA WORK 20/57 Carabiniers' Memorial; WORK 20/59 Royal Artillery Memorial, 1905-1912;

WORK 20/55 Royal Marines' Memorial, 1901-1911;GL, December 1900, p. 139; HAC Court

Minutes, 19 January 1903

${ }^{29}$ See $G L$, December 1900, p. 139; TNA WORK 20/55 Royal Marines' memorial, letter from

Lieutenant-General A. French to Office of Works, 31 October 1901

${ }^{30}$ The Times, 9 July 1910

${ }^{31}$ The Alleynian, June 1901, p. 163

${ }^{32} J C, 29$ January 1904

${ }^{33}$ IR, 26 December 1902; J. Gildea, For Remembrance and in Honour of Those Who Lost Their Lives in the South African War, 1899-1902 (London: Eyre and Spottiswoode Ltd, 1911) p. 146

${ }^{34}$ IDG, 19 May 1904

${ }^{35} I D G, 14$ July 1905

${ }^{36}$ Bill Nasson, The South African War 1899-1902 (London: Arnold, 1999) pp. 238-239

${ }^{37}$ For a good summary of the arguments see Ian Beckett, The Victorians at War (London: Hambledon and London, 2003) pp. 222-224

${ }^{38}$ See Jose Harris, Private Lives, Public Spirit. A social history of Britain, 1870-1914 (Oxford: Oxford University Press, 1993) pp. 194-195; P. Thompson, Socialists, Liberals and Labour. The Struggle for London, 1885-1914 (London: Routledge and Kegan Paul, 1967) pp. 5-16

${ }^{39}$ See William Kidd and Brian Murdoch (eds), Memory and memorials. The commemorative century (Aldershot: Ashgate, 2004) p. 4

${ }^{40}$ Victoria County History of Middlesex Vol. VIII (Oxford: Oxford University Press, 1985) p. 13

${ }^{41}$ Mary Cash, A History of Islington (London: Historical Publications Ltd, 2005) pp. 325-329

42 Victoria County History, p. 11

${ }^{43}$ Victoria County History, pp. 13, 101-115; Cash, Islington, pp. 235-249. See reports in Islington Gazette, 10 June 1902 for the reaction of nonconformist communities to the war. For a wider discussion of nonconformity and the South African War see Alan Wilkinson, The Church of England and the First World War (London: SPCK, 1978) pp. 10-11, 16, 30, 176, 202, 295 and Stephen Koss (eds), Pro-Boers: the anatomy of an anti-war movement (Chicago: Chicago University Press, 1973) ${ }^{44} I D G, 13$ October 1903

${ }^{45}$ Hugh Cunningham, The Volunteer Movement: a Social and Political History, 1859-1908, (Hamden, Connecticut: Achon Books, 1975) pp.128-29

${ }^{46}$ Chaplin, The Queen's Own Royal West Kent Regiment, p. 108

${ }^{47}$ EKA, DoCA17/1/17, South African War Memorial Committee, minutes, 6 May 1904

${ }^{48}$ FE, 23 April 1904

${ }^{49}$ The $2^{\text {nd }}$ Volunteer Battalion of The Buffs' memorial was erected in St Dunstan's parish church, Cranbrook; the Royal West Kent's equivalent can be found in St Alfege's parish church, Greenwich.

${ }^{50}$ Cunningham, The Volunteer Movement, pp. 127 -35

${ }^{51}$ Tonbridge School Archive, The Tonbridgian, June 1902, p. 2116; TFP, 24 June 1904.

${ }_{52}^{52}$ CCA, CC/BB149, Canterbury City Council, minutes, 13 April 1923.

${ }^{53}$ HAC Court Minutes, 19 January 1903

${ }^{54}$ The Alleynian, June 1901, p. 163

${ }^{55} I D G, 13$ October 1903. For the debate over utilitarian schemes in Scotland see Spiers, The Scottish

Soldier and Empire, pp. 205-206

${ }^{56} I D G, 14$ October 1903

${ }^{57} I D G, 15$ October 1903

${ }^{58} I D G, 15$ October 1903

${ }^{59}$ TFP, 24 June 1904; QOG, Vol. XX, No. 6, June 1902, p1760; FE, 23 April 1904

${ }^{60}$ HAC Court Minutes, 19 January, 30 March 1903; City Press, 8 June, 20 July 1904

${ }^{61}$ HAC Court Minutes, 21 March, 11 April 1904

${ }^{62}$ Ilford Urban District Council Minutes, 13 September 1904; IR, 17 November 1905

${ }^{63}$ Victoria County History of Essex, Vol. V (Oxford: Oxford University Press, 1966) pp. 5-6, 251. See also Connelly, The Great War, pp. 16-17

${ }^{64}$ See Michael Sanderson, Education and Economic Decline in Britain, 1870 to the 1990s (Cambridge: Cambridge University Press, 1999) pp. 40-54 
${ }^{65}$ Lawrence E. Tanner, Westminster School. Its buildings and their associations (London: Philip Allan and Co, 1923) p. 30

${ }^{66}$ McDonnell, St Paul's School, p. 445

${ }^{67}$ The Alleynian, Vol. XXXI, No. 228, July 1903, pp. 224-225

${ }^{68}$ See Roy Strong, And when did you last see your father? The Victorian painter and British History (London: Thames and Hudson, 1978) pp. 113-161

${ }^{69}$ See Lynda Nead, Victorian Babylon. People, streets and images in nineteenth-century London (New Haven and London: Yale University Press, 2000) pp. 9, 23

70 TNA WORK 20/59 Royal Artillery memorial, Office of Works memorandum, 12 December 1905

${ }^{71}$ See Bernard Porter, 'The Pro-Boers in Britain' in Warwick (ed), The South African War, pp. 239258, pp. 236, 245-246

72 See David Feldman, Englishmen and Jews. Social relations and political culture, 1840-1914 (New Haven and London: Yale University Press, 1994) pp. 261-311

${ }^{73}$ JC, 15 July 1904

${ }^{74}$ JC, 15 July 1904

${ }^{75}$ See Connelly, The Great War, pp. 212-229. A replica of the South African War memorial was erected in the synagogue for the use of Jewish soldiers at Aldershot camp and unveiled in a special ceremony, see Sheldrake's Aldershot Military Gazette, 29 March 1912

${ }^{76}$ For details on Colton's career see British Sculpture, 1850-1914 (London: Fine Arts Society, 1968), p. 28

77 TNA WORK 20/59 Royal Artillery memorial. Letter from Lord Esher 9 November 1905. See also his letter of 13 November 1905

78 TNA WORK 20/59 Royal Artillery memorial, Office of Works memorandum, 12 December 1905

${ }^{79}$ TNA WORK 20/59 Royal Artillery memorial. Secretary of Office of Works [Sir Shomberg McDonnell] to Lord Knollys [Royal Private Secretary], 9 December 1905

${ }^{80}$ TNA WORK 20/59 Royal Artillery memorial. Letter from McDonnell to Colton, 16 July 1906

${ }^{81}$ TNA WORK 20/59 Royal Artillery memorial. Letter from Colton to McDonnell, 16 November 1906

82 TNA WORK 20/59 Royal Artillery memorial. Letters between McDonnell and Colton, 15, 17 December 1906

${ }^{83}$ TNA WORK 20/59 Royal Artillery memorial. Letter from McDonnell to Thomas Brock, 9 May 1909.

${ }^{84}$ TNA WORK 20/59 Royal Artillery memorial. Letter from McDonnell to Esher, 10 June 1909

85 TNA WORK 20/59 Royal Artillery memorial. Letter from Colton to McDonnell, 30 September 1909

${ }^{86}$ TNA WORK 20/59 Royal Artillery memorial. Memorandum by McDonnell, 25 April 1906

${ }^{87}$ The Times, 9 July 1910

${ }^{88}$ The Times, 21 July 1910

${ }^{89}$ The Times, 23 July 1910

${ }^{90}$ The Times, 26 July, 2 August 1910

${ }^{91}$ REM, RO270, Royal Engineers' War Memorial Committee, letter from Colonel E. Lloyd to the memorial committee, 7 November 1902

${ }^{92}$ REM, RO270, letter from Kitchener to Sir T. Fraser, 21 May 1902.

${ }^{93}$ REM, RO270, Royal Engineers War Memorial Committee, minutes, 24 October 1902

${ }^{94}$ REM, RO270, Royal Engineers War Memorial Committee, minutes, 21 November 1902

${ }^{95}$ REM, RO270, Royal Engineers War Memorial Committee, minutes, 19 December 1902

${ }^{96}$ Alex King, Memorials of the Great War in Britain (Oxford: Berg, 1998) pp. 11-15

${ }^{97}$ Alan Borg has traced the triumphal back to the removal of Egyptian obelisks by the Romans. Alan Borg, War Memorials; from Antiquity to the Present (London: Leo Cooper, 1991) pp.2-4

${ }^{98}$ REM, RO270, Royal Engineers War Memorial Committee, minutes, 24 October 1902. The battle of Majuba Hill on 27 February 1881 was a decisive defeat for the British in the First Boer War and not only paved the way for the granting of internal independence to the Transvaal but was also viewed both domestically and internationally as a hugely humiliating loss of face for the British army. See Thomas Pakenham, The Boer War (London: Weidenfeld and Nicolson, 1979) pp.130-34

${ }^{99}$ See Bill Nasson, The South African War 1899-1902 (London: Arnold, 1999) pp. 227-233

${ }^{100}$ REM, RO2070, letter from Major Hildebrand to Royal Engineers War Memorial Committee, undated

${ }^{101}$ REM, RO270, Royal Engineers War Memorial Committee, minutes, 6 June 1903. Later in the same meeting, Wood explicitly disassociated himself from ownership of the sketch by insisting that, 'The sketch was not ....in any sense my sketch, except that I embodied the ideas of Lord Kitchener in that sketch'. 
102 REM, RO270, Royal Engineers War Memorial Committee, minutes, 6 June 1903.

${ }^{103}$ REM, RO270, Royal Engineers War Memorial Committee, minutes, 6 June 1903.

${ }^{104}$ REM, RO270, Royal Engineers War Memorial Committee, minutes, 6 June 1903. The was a tactic that would be deployed with greater regularity in the more heated and protracted debates over commemorative form in the aftermath of the First World War. See Peter Donaldson, Ritual and Remembrance, The Memorialisation of the Great War in East Kent, (Cambridge, CSP, 2006) p72 ${ }^{105}$ REM, RO270, Royal Engineers War Memorial Committee, minutes, 6 June 1903.

106 See page 2 above.

${ }^{107}$ Ingress Bell had previously worked as a surveyor for the War Office and was a partner of Aston Webb, the then president of the Royal Institute of British Architects. See R. Dixon and S. Muthesius, Victorian Architecture, (London, Thames and Hudson: 1978) p269.

108 The political significance of the Boer statues was once again brought into high relief in the aftermath of the First World War. In December 1920, General Smuts, the Prime Minister of South Africa, approached Alfred Milner, the Secretary of State for the Colonies, requesting their return. Milner duly obliged for, in his words, 'political reasons... as an act of goodwill'. REM, The Sapper, Vol. 26, No. 307, February 1921 p. 99

${ }^{109}$ IDG, 17 May 1905. For details on Mackennal's career see British Sculpture, 1850-1914, p. 28

${ }^{110} I D G, 7$ July 1903

${ }^{111} I D G, 17$ May 1905

${ }^{112} I D G, 7,13,14$ October 1903

${ }^{113}$ EKA, DoCa/10/5/7, South African War Fund Committee, minutes 13 November 1899; EKA, Do/AMS/3, Queen Victoria Memorial Committee, minutes, 19 June 1901. Lord Stanhope, the chairman of the public meeting held to discuss moves for a county relief fund and memorial scheme, made plain just how real the danger of donor fatigue was when he told those assembled at Maidstone town hall that 'he had no doubt there would be a large fund in time, even though it was the year of the Coronation and there were funds for bonfires and feedings and all kinds of rejoicing'. QOG, Vol. XX, No. 6, June 1902, p1760.

${ }^{114}$ EKA, Do/CA17/1/17, South African Memorial Committee, minutes, 6 May 1904

115 Although financial difficulties clearly played a part in the extraordinary delay in the completion of Dover's memorial scheme, one can't help thinking that there must have been more to it. One possible explanation may lie in the competing demands on hard-pressed civic officials' time. Certainly Alderman Mowll, the mayor of Dover, was quick to present this excuse for the late launch of the scheme. In a letter to the editor of the Dover Express, he explained that the delay had come about 'because the Proclamation of Peace had been followed by the serious illness of the King, his own illhealth, the welcoming home of the troops and other duties which had made it impossible at that time to consider the matter'. DE, 13 May 1904. This, of course, doesn't explain why it took another eight years before the memorial was ready to be unveiled, and here the records hold no clue.

116 The Alleynian, 1901: July, p. 221; October, p. 319; November, p. 375; 1902: February, pp. 8-9; April, p. 64; May, pp. 114-115; October, pp. 272-273; November, p. 339; 1903: June, pp. 159-160 117 The Times, 9 July 1910; TNA WORK 20/59 Royal Artillery memorial. Memorandum by McDonnell, 9 January 1906

${ }^{118}$ Historical Record of the $3^{\text {rd }}$ County of London (Sharpshooters) Imperial Yeomanry, 1900-1905 (London: no imprint, 1905) pp. 67-68

${ }^{119}$ City Press, 14 October 1903

${ }^{120}$ KGCP, 28 November 1903

${ }^{121}$ The Tonbridgian, August 1905, p. 129

122 The Tonbridgian, August 1905, p. 130

${ }^{123}$ City Press, 18 January 1908

${ }^{124}$ In the 1900 election Kent returned 14 Conservative MPs and one Liberal. Yates (ed.), Kent in the Twentieth Century, pp. 153-4

${ }^{125}$ The Langtonian, Vol. 9, No. 4, December 1903, p. 62 It should be noted that it was not just Harris' service record but also his business interests, he was chairman of the Rhodes Consolidated Goldfields and the South African Gold Trust, that help to provide a rationale for the views presented to the boys of Simon Langton School

${ }^{126}$ TFP, 15 April 1904; TFP, 24 June 1904

127 TFP, 24 June 1904.

${ }^{128}$ TFP, 24 June 1904. The decision to invite Buller to unveil the memorial must have owed a lot to the presence of John Le Fleming on the memorial committee. Le Fleming had been at University with Buller and his son had served under him in South Africa. 
${ }^{129}$ The Langtonian, Vol. 9, No. 4, December 1903, p. 62

${ }^{130}$ The Langtonian, Vol. 9, No. 4, December 1903, p. 62

${ }^{131}$ The Tonbridgian, August 1905, p. 128

${ }^{132}$ The Alleynian, Vol. XXI, No. 228, July 1903, pp. 224-225

${ }^{133}$ JC, 24 March 1905

${ }^{134} D E, 25$ April 1912

${ }^{135}$ CN, 29 July 1905

${ }^{136}$ REM, RO2070, War Memorial Unveiling Supplement, RE Journal, Vol. XXXVIII, No. 6, September 1905, p. 108

${ }^{137}$ TFP, 24 June 1904. It should also be noted that Fitch-Kemp, in not dwelling on military matters, was tactfully avoiding having to make any reference to Buller's controversial dismissal from the army (see also page 11).

${ }^{138}$ Hampstead Advertiser, 23 December 1902

${ }^{139}$ Hampstead Advertiser, 23 December 1902

${ }^{140} I R, 26$ December 1902

${ }^{141}$ City Press, 8 June 1904

${ }^{142}$ See Wilkinson, The Church of England

${ }^{143}$ Unfortunately, the confines of an article do not provide the space to explore the significance of street names as memorials. The burgeoning suburbs of London saw a rash of streets named in commemoration of the war. It is therefore possible to find Edwardian estates with the following names: Tottenham Hale - Ladysmith, Mafeking, Kimberley, Buller roads; Wood Green - Redvers Buller Road; Upper Norwood - Buller, Kitchener, Natal, Hamilton, Milner roads; East Ham - Mafeking, Kimberley, Ladysmith avenues; West Ham - Kimberley, Mafeking, Pretoria roads. The most comprehensive can be found in Ilford - Colenso Road, Kimberley, Glencoe, Durban, Mafeking, Ladysmith avenues. See Alan A. Jackson, Semi-Detached London. Suburban Development, Life and Transport, 1900-39 (London: George Allen and Unwin, 1973) p. 62 